\title{
A scoping review of researchers' involvement in health policy dialogue in Africa
}

Doris Yimgang ${ }^{1}$, Georges Danhoundo ${ }^{2}$, Elizabeth Kusi-Appiah³ ${ }^{3}$ Vijit Sunder ${ }^{4}$, Sandra Campbell ${ }^{3}$ and Sanni Yaya ${ }^{5,6^{*}}$ (i)

\begin{abstract}
Background: Improving evidence-informed policy dialogue to support the development and implementation of national health policies is vital, but there is limited evidence on researchers' roles in policy dialogue processes in Africa. The objective of this study is to examine researchers' involvement in health policy dialogue in Africa.

Methods: The database search of this scoping review was conducted from inception to January 24, 2021, by an expert searcher/librarian to determine the extent of evidence, barriers, and facilitators of researchers' involvement in health policy dialogues in Africa. PROSPERO, Wiley Cochrane Library, OVID Medline, OVID EMBASE, OVID PsycINFO, OVID Global Health, EBSCO CINAHL, BASE (Bielefeld Academic Search Engine), and Google/Google Scholar were searched using key words representing the concepts "policy dialogue", "health", and "Africa". No limits were applied. A narrative summary of results was presented.

Results: There were 26 eligible studies representing 21 African countries. Significant discrepancies in researchers' involvement existed across countries. In $62 \%$ of the countries, there was suboptimal involvement of researchers in policy dialogues due to no or partial participation in policy dialogues. Major barriers included limited funding, lack of evidence in the public health field of interest, and skepticism of policymakers. The presence of an interface for exchange, demand for scientific evidence, and donors' funding were the most reported facilitators.

Conclusions: To improve the uptake of evidence in health policy-making processes, an environment of trust and communication between policymakers and researchers must be established. Policymakers need to demonstrate that they value research, by providing adequate funding, promoting knowledge translation activities, and supporting personal and professional development opportunities for researchers.
\end{abstract}

Keywords: Health policy dialogue, Researchers' involvement, Africa, Barriers, Facilitators

\footnotetext{
* Correspondence: sanni.yaya@uottawa.ca

${ }^{5}$ School of International Development and Global Studies, University of Ottawa, 120 University Private, Ottawa, Ontario K1N 6 N5, Canada

${ }^{6}$ The George Institute for Global Health, Imperial College London, London, UK

Full list of author information is available at the end of the article
}

(c) The Author(s). 2021 Open Access This article is licensed under a Creative Commons Attribution 4.0 International License, which permits use, sharing, adaptation, distribution and reproduction in any medium or format, as long as you give appropriate credit to the original author(s) and the source, provide a link to the Creative Commons licence, and indicate if changes were made. The images or other third party material in this article are included in the article's Creative Commons licence, unless indicated otherwise in a credit line to the material. If material is not included in the article's Creative Commons licence and your intended use is not permitted by statutory regulation or exceeds the permitted use, you will need to obtain permission directly from the copyright holder. To view a copy of this licence, visit http://creativecommons.org/licenses/by/4.0/ The Creative Commons Public Domain Dedication waiver (http://creativecommons.org/publicdomain/zero/1.0/) applies to the data made available in this article, unless otherwise stated in a credit line to the data. 


\section{Background}

The gap between research and health policy development in low- and middle-income countries appears uncontended. Mounting evidence demonstrates that the health policy-making process in these countries is prescriptive, insufficiently evidence-based, and inconsiderate of contexts [1,2]. The political tussle over the formation of values and ideas informing health policy directives increases the propensity for misusing the already scarce resources, which hampers the economic growth and worsens the instability of social systems [3]. Globally, researchers and academic experts, largely considered to be well-informed citizens, discourage the formation of policies based on decision-makers' personal ideas, interests, or experiences $[1,4]$. Looking at the formation of health policies in the African context, Siron and his colleagues [5] identified that the increasingly politicized health policy decisions are driven by the ideological motivations of stakeholders who overlook research evidence to advance their political interests.

The global concern for evidenced-informed policies in Africa relates to the humanitarian call to build the capacity of local policy actors for developing evidence informed health policies [3, 6, 7]. For instance, in 2011 the European Union, World Health Organization (WHO), and the Government of Luxembourg formed a partnership to help build the capacity of developing countries for evidence-informed health policies using policy dialogue [6]. Nonetheless, researchers' involvement in policy dialogue in Africa remains unclear.

The complicated relationship between researchers and politicians sparked the creation of deliberative dialogue platforms, to facilitate the process of multiple stakeholders participating in evidence-informed policy decision-making [7]. Policy dialogue is a participatory approach to policy making based on evidence, deliberative discussion, workshop interaction, and consultation $[8,9]$. A strong and independent policy research organization can play an important role in informing and shaping policies for the greatest good of the public [10]. The sustained development of capacity for health policy research and uptake of evidence is a key priority for WHO. The Organization promotes efforts towards fostering and encouraging a culture of evidenceinformed decision-making through strengthening the capacity of research institutions and stimulating the interest of policymakers [11].

The process of policy influence through research is complex and non-linear and demands much more than an ability to produce high caliber research [12]. Some researchers operate in environments with traditions of social participation; others have limited input. Despite these differences, all health researchers must grapple with political realities in their local contexts. A reflective and cross-sectional analysis of national deliberative policy dialogue workshops in six west African countries reported by Riddle and Dagenais [7] suggested that there are several challenges related to the facilitation of successful evidenced-informed policy dialogue. As such, researchers need the capacity not just to produce knowledge, but to navigate in complex terrain. There is scant evidence on factors that affect researchers' involvement and contribution to health policy dialogue in Africa. This paper explores the current practice of policy dialogue in relation to the incorporation of research evidence for health policy formation in the African context. Therefore, a scoping review was conducted to examine the researchers' involvement range, researchers' roles, facilitators, and barriers to researcher's involvement in health policy dialogue in Africa.

\section{Methods}

A scoping review was conducted to determine the range and nature of research activity concerning the barriers and facilitators of researchers' involvement in health policy dialogues in Africa. A scoping review is a research methodology used to identify key factors related to a concept, to map the available evidence, and discuss the concept or key factors [13]. The preferred reporting items for systematic reviews and meta-analyses extension for scoping reviews (PRIS MA-ScR) checklist was used to present the study methodology and findings $[14,15]$.

\section{Identification of the research question}

Our research question was "what are the facilitators and barriers to researcher's involvement in health policy dialogue in Africa?"

\section{Protocol}

We used the preferred reporting items for systematic reviews and meta-analysis protocols (PRISMA-P) to develop our protocol, which is available in Additional file 1.

\section{Identification of the relevant studies}

A search was executed by an expert searcher/librarian (SC) in the following databases: PROSPERO, Wiley Cochrane Library, OVID Medline, OVID EMBASE, OVID PsycInfo, OVID Global Health, and EBSCO CINA HL, using controlled vocabulary (e.g. MeSH, Emtree, etc.) and key words representing the concepts "policy dialogue" and "health" and "Africa". Databases were searched from inception to January 24, 2021. To broadly capture the existing literature, no limits were applied. Grey literature searches were conducted in BASE (Bielefeld Academic Search Engine) and Google/Google Scholar. Results $(n=513)$ were exported to RefWorks 
citation management system. Detailed search strategies are available in Additional file 2.

\section{Study selection}

Two co-authors (DY and GD) independently screened titles and abstracts of identified papers. After full-text screening by a co-author (EK-A), papers were then categorized into case studies, commentary, structured reflection, and quantitative studies. Four co-authors (DY, EK-A, GD, VS) carried out full-text extraction using a data extraction sheet developed for the purpose of this study. Researchers first verified that papers met inclusion criteria and focused on the topic of interest. Discrepancies in reviewers' responses at abstract and full article screenings were resolved through discussion.

\section{Inclusion and exclusion criteria}

Studies were included in this review if they met the following criteria: (1) peer-reviewed papers or grey literature on health policy dialogue, (2) reporting findings from programs or interventions conducted in Africa, and (3) describing country-level policy dialogue. Studies were excluded if papers were reviews, protocols, editorials, or other opinion pieces, and authors were not identified.

\section{Data charting}

Each paper was independently reviewed by two authors, who discussed charted data and updated the data extraction sheet accordingly. Any disagreements were resolved through further adjudication by a third author. An excel data sheet was used to organize data extracted from each paper into themes. Information extracted from the selected studies were organized and categorized as follows: authors and publication date, country, study type, public health issue that triggered the policy dialogue, description of the policy window, organizers of the policy dialogue, actors involved in the policy dialogue and their roles, contribution of researchers to the policy dialogue, presence of local researchers, barriers and facilitators of researchers' involvement in policy dialogue, and outcome of the policy dialogue.

\section{Collating and summarizing findings}

A thematic data-synthesis was performed to identify contextual barriers and facilitators of researcher's involvement in health policy dialogue. The synthesis includes useful information on the underlying processes of the public health issue that triggered the policy dialogue, policy window under scrutiny, actors involved in the policy dialogue and their roles, and contribution of researchers to the policy dialogue.
To provide an overview of the findings, a narrative summary of results is presented given the heterogeneity of study designs, objectives, and outcomes.

\section{Results}

Search results

A preliminary search of scientific databases and grey literature yielded a total of 513 studies. After removing the duplicates $(n=115)$, titles and abstracts of 398 studies were screened excluding an additional 346 studies and leaving a sample of 52 studies. Screening of full texts yielded a total sample of 26 studies eligible for this review. A complete study flow diagram is shown in Fig. 1.

\section{Study characteristics}

Studies included in this review were published between 2005 and 2020. Studies focused on Africa with twenty-one [16] countries represented and seven [7] multinational studies, involving more than one African country. Uganda had the most studies $(n=6)$, followed by South Africa $(n=3)$, Benin $(n=3)$, Nigeria $(n=3)$, Burkina Faso $(n=2)$, Ghana $(n=2)$, Malawi $(n=2)$, Mali $(n=2)$, Senegal $(n=2)$, and Tanzania $(n=2)$. One study from each of the following countries was included: Cabo Verde, Cameroon, Chad, Guinea, Ivory Coast, Liberia, Morocco, Mozambique, Niger, Zambia, and Zimbabwe.

The most common study design was case study $(n=$ 16) with qualitative data describing policy dialogue in specific settings. Additional qualitative studies included: commentary $(n=1)$, exploratory study $(n=1)$, desk review $(n=1)$, reflective analysis $(n=1)$, and participatory action research $(n=1)$. These studies were primarily supported by international funding (19 out of 26), and 21 studies receiving technical support from international agencies or governments, with the main funder being WHO $(n=16)$. Local government officials (such as the President or Prime Minister) or ministry of health $(\mathrm{MoH})$ initiated the dialogue in 11 studies. Content areas varied across studies with the most predominant being malaria $(n=5)$, HIV/AIDS $(n=4)$, maternal and child health $(n=5)$, and discussion of gaps in evidence uptake in health policy $(n=4)$.

\section{Stakeholders participating in policy dialogue}

Policy dialogues were mainly organized in the context of poor health outcomes, change in health service delivery, the need for research evidence in policy development, or the development of new health policies (Fig. 2). Varied stakeholders attended policy dialogue with the participation of researchers acknowledged in 18 studies, in which local researchers were involved as subject matter experts in the public health being discussed (Table 1). In 65\% of the studies $(n=17)$, researchers actively participated in 


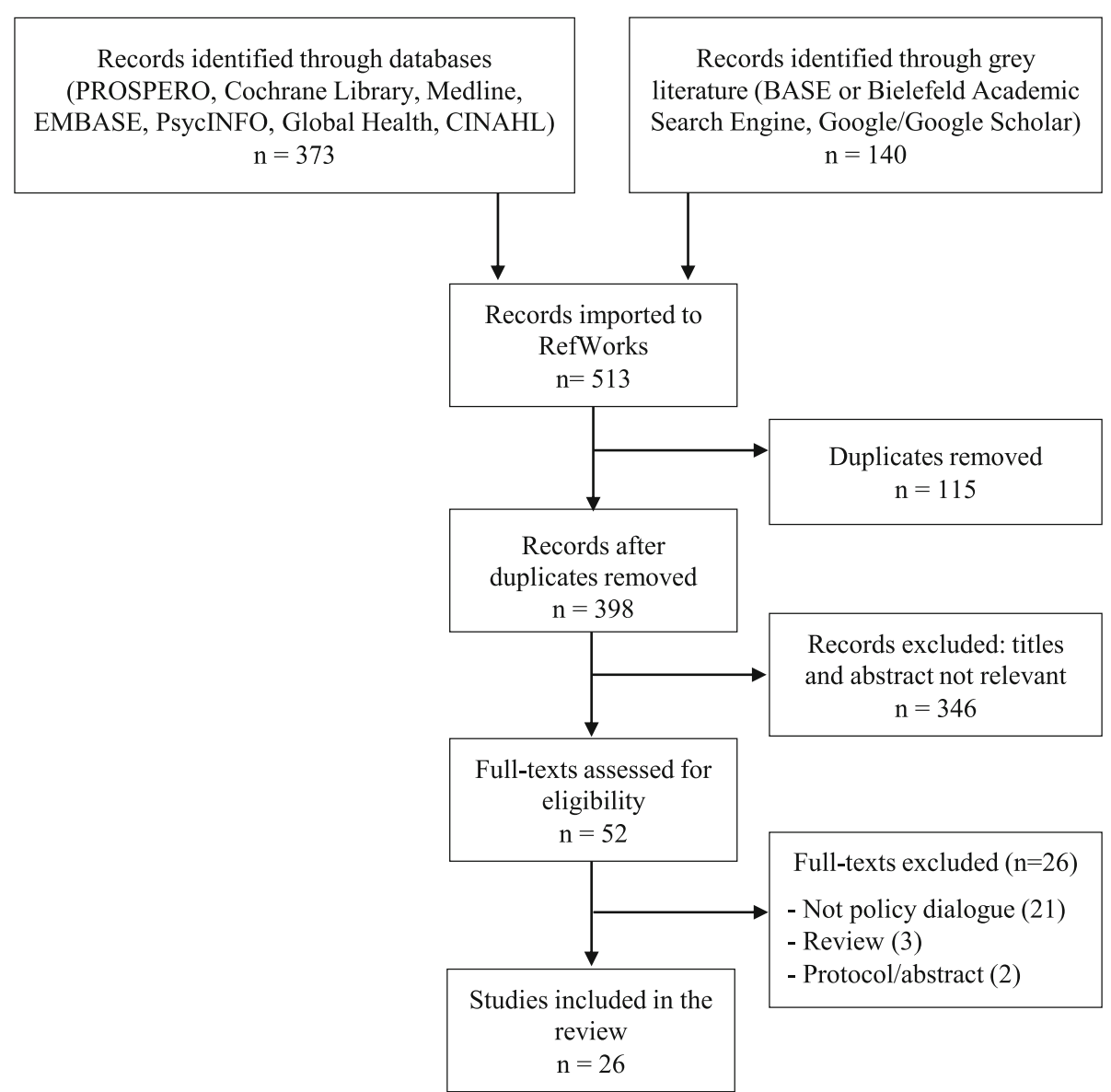

Fig. 1 Study flow diagram

the policy dialogue, and they performed tasks such as generating evidence, developing policy briefs, organizing or facilitating policy dialogues, assisting policymakers by summarizing evidence and making recommendations, and supporting the policy implementation process. Researchers had a more passive role in one study [37]; their responsibilities consisted of organizing the policy dialogue and collecting data without being part of the discussion. Policymakers attended almost all the meetings (25 out of 26). Only one study did not report the participation of policymakers in the policy dialogue due to the lack of government initiative to change policy regarding HIV/AIDS health service delivery in South Africa [33]. Civil society organizations initiated the policy process, established platforms to discuss with other stakeholders (including researchers, business organizations, and the African trade union), and collaborated on the development of policy plans [33]. After much advocacy efforts that resulted in antiretroviral price reductions, the government joined in the efforts to improve HIV/AIDS health service delivery [33]. Other commonly reported stakeholders attending policy dialogues included civil society $(n=16)$, health professionals $(n=9)$, donors $(n$ $=8)$, the media $(n=7)$, the public or community members $(n=7)$, and international agencies $(n=7)$.

\section{Researchers' roles in health policy dialogue across countries}

Few countries featured successful researchers' involvement in all their studies or national policy dialogues. For instance, researchers actively participated in all six studies from Uganda. Researchers helped generate evidence $(n=4)$, developed and reviewed policy briefs $(n=6)$, and organized dialogues or participated in discussions ( $n$ =6). Major facilitators in this setting included shared platforms for knowledge translation, sustained collaboration between researchers and policymakers, and demand for research evidence. In South Africa, researchers participated in all three studies, but their roles varied based on their involvement. Sabi and colleagues described the involvement of researchers in developing policy proposals to support change in HIV/AIDS health delivery service initiated by civil society organizations [33]. Young and colleagues reported that researchers 


\begin{tabular}{|l|}
\hline Triggering factors \\
\hline Poor health outcomes \\
Change in health service delivery \\
Need for evidence \\
New health policy \\
\hline
\end{tabular}

\begin{tabular}{|l|}
\hline Top reported stakeholders \\
\hline Policymakers/MoH (26) \\
\hline Researchers (17) \\
\hline Civil society (16) \\
\hline Health professionals (9) \\
\hline Donors (8) \\
\hline Media (7) \\
\hline Public/community (7) \\
\hline International agencies (7) \\
\hline Policy implementers (4) \\
\hline Other ministries (3) \\
\hline Private sector (3) \\
\hline
\end{tabular}

\begin{tabular}{|l|l|}
\hline \multicolumn{2}{|c|}{ Top reported barriers } \\
\hline For other stakeholders & For researchers \\
\hline Limited funding (8) & Lack of relevant data and evidence (7) \\
\hline Skepticism of policymakers or government (3) & Limited time (3) \\
\hline $\begin{array}{l}\text { Unavailability of appropriate methodology or } \\
\text { framework (3) }\end{array}$ & $\begin{array}{l}\text { Preference for "hands-off" approaches to } \\
\text { dissemination of findings (2) }\end{array}$ \\
\hline Use of medical or scientific jargon (2) & Lack of engagement with other stakeholders (2) \\
\hline Absence of knowledge translation platforms (2) & \\
\hline Limited availability of researchers (2) & \\
\hline
\end{tabular}

\begin{tabular}{|l|l|}
\hline \multicolumn{2}{|c|}{ Top reported enablers } \\
\hline For other stakeholders & For researchers \\
\hline Presence of interface for exchange (11) & Motivation to contribute to public health (2) \\
\hline Demand for scientific evidence (5) & Networking with experts (2) \\
\hline Donors' funding and involvement (5) & Prospects for career development (1) \\
\hline Trust and respect of researchers (4) & \\
\hline Strong political will (4) & \\
\hline Preparatory phase (2) & \\
\hline Clear and simple communication (2) & \\
\hline
\end{tabular}

Fig. 2 Summary of triggering factors, barriers, and facilitators of researchers' involvement in policy dialogue

were paired with policymakers to increase the uptake of evidence in health policy decisions; researchers helped with clarifying research questions, appraising systematic reviews, preparing short evidence summaries, and providing feedback to policymakers [39]. In South Africa, Mozambique, and Zimbabwe, researchers participated in shaping policies around eclampsia treatment and malaria control, and they participated in generating evidence and policy development in collaboration with other stakeholders [38]. Facilitators of researchers' involvement in policy dialogues from these three countries included the involvement of local researchers in randomized trials conducted to generate evidence to support policy change. In Malawi, researchers actively participated in all two policy dialogues: one addressing abortion complications [23], and the other targeting the development of a knowledge translation platform [16]. To promote evidence uptake in health policy dialogue through the development of a shared platform, the Ministry of Health built partnerships with different stakeholders and defined roles of each actor in the process of making evidence-informed health policies [16]. Researchers actively participated in workshop's facilitation and building capacity in developing research summaries and policy briefs [16].

Several countries had researchers engaged in some of their policy dialogues but not others. For instance, one of the two studies conducted in Burkina Faso reported researchers' participation in the policy dialogue. Researchers conducted the research to generate evidence around road traffic injuries, and they organized policy workshops to disseminate findings and discuss 
Table 1 Characteristics of publications on policy dialogue in Africa

\begin{tabular}{|c|c|c|c|c|c|c|}
\hline $\begin{array}{l}\text { Author and } \\
\text { date }\end{array}$ & Country & Study type & Public health issue & $\begin{array}{l}\text { Participants in policy } \\
\text { dialogue }\end{array}$ & Role of researchers & $\begin{array}{l}\text { Presence } \\
\text { of local } \\
\text { researchers }\end{array}$ \\
\hline $\begin{array}{l}\text { Ade et al. } \\
2016 \text { [17] }\end{array}$ & Guinea & Case study & National health policy & $\begin{array}{l}\text { MoH, civil society, } \\
\text { development partners, } \\
\text { Ministry of Environment }\end{array}$ & Not reported & $\begin{array}{l}\text { Not } \\
\text { reported }\end{array}$ \\
\hline $\begin{array}{l}\text { Akhnif et al. } \\
2020 \text { [18] }\end{array}$ & Morocco & Case study & Health financing & $\begin{array}{l}\text { Key ministries, media, } \\
\text { parliamentarians, private } \\
\text { sector, researchers, civil } \\
\text { society, health } \\
\text { professionals, technical } \\
\text { and financial partners }\end{array}$ & $\begin{array}{l}\text { Active-organized } \\
\text { workshops, participated and } \\
\text { contributed to dialogue, and } \\
\text { documented discussions }\end{array}$ & Yes \\
\hline $\begin{array}{l}\text { Berman } \\
\text { et al. } 2015 \\
{[16]}\end{array}$ & Malawi & Commentary & $\begin{array}{l}\text { Development of knowledge } \\
\text { translation platform }\end{array}$ & $\begin{array}{l}\text { Researchers, policymakers, } \\
\text { implementers, civil society }\end{array}$ & $\begin{array}{l}\text { Active-generated evidence, } \\
\text { developed policy briefs, } \\
\text { facilitated policy dialogue }\end{array}$ & Yes \\
\hline $\begin{array}{l}\text { Burris et al. } \\
2011 \text { [19] }\end{array}$ & Ghana & Case study & $\begin{array}{l}\text { HIV-herpes simplex virus } \\
\text { type-2 interaction }\end{array}$ & Researchers, policymakers, & $\begin{array}{l}\text { Active-generated evidence, } \\
\text { contributed to policy } \\
\text { development }\end{array}$ & Yes \\
\hline $\begin{array}{l}\text { De Carvalho } \\
\text { et al. } 2014 \\
\text { [20] }\end{array}$ & Ghana & Case study & Aging and health & $\begin{array}{l}\text { Key ministries, the Ghana } \\
\text { Health Service, teaching } \\
\text { hospitals, professional } \\
\text { bodies, HelpAge Ghana, } \\
\text { WHO }\end{array}$ & Not reported & $\begin{array}{l}\text { Not } \\
\text { reported }\end{array}$ \\
\hline $\begin{array}{l}\text { Dossou } \\
\text { et al. } 2018 \\
{[21]}\end{array}$ & Benin & Case study & $\begin{array}{l}\text { User fees for caesarian } \\
\text { section }\end{array}$ & $\begin{array}{l}\text { MoH, implementers, } \\
\text { healthcare professionals, } \\
\text { economists, civil society }\end{array}$ & Not reported & $\begin{array}{l}\text { Not } \\
\text { reported }\end{array}$ \\
\hline $\begin{array}{l}\text { Dovlo et al. } \\
2016[6]\end{array}$ & $\begin{array}{l}\text { Multinational-_ } \\
\text { Cabo Verde, } \\
\text { Chad, Mali }\end{array}$ & $\begin{array}{l}\text { Exploratory } \\
\text { study }\end{array}$ & $\begin{array}{l}\text { Improvement of national } \\
\text { health development }\end{array}$ & $\begin{array}{l}\text { MoH, donor agencies, civil } \\
\text { society }\end{array}$ & Not reported & $\begin{array}{l}\text { Not } \\
\text { reported }\end{array}$ \\
\hline $\begin{array}{l}\text { Johnson } \\
\text { et al. } 2020 \\
\text { [22] }\end{array}$ & Nigeria & Case study & Maternal child health & $\begin{array}{l}\text { Policymakers, technical } \\
\text { and financial partners, } \\
\text { civil society, researchers, } \\
\text { healthcare professionals }\end{array}$ & $\begin{array}{l}\text { Active-participated in } \\
\text { discussions, }\end{array}$ & Yes \\
\hline $\begin{array}{l}\text { Kinoti et al. } \\
2014 \text { [23] }\end{array}$ & $\begin{array}{l}\text { Multinational- } \\
\text { Malawi, } \\
\text { Uganda, } \\
\text { Zambia }\end{array}$ & Not reported & Abortion complications & $\begin{array}{l}\text { Researchers, policymakers, } \\
\text { healthcare providers }\end{array}$ & $\begin{array}{l}\text { Active_conducted research, } \\
\text { disseminated findings, } \\
\text { participated in dialogues, } \\
\text { developed action plans }\end{array}$ & Yes \\
\hline $\begin{array}{l}\text { Kirigia et al. } \\
2016 \text { [24] }\end{array}$ & $\begin{array}{l}\text { Multinational- } \\
\text { African region }\end{array}$ & Not reported & $\begin{array}{l}\text { Increase uptake of evidence } \\
\text { in health policy and practice }\end{array}$ & $\begin{array}{l}\text { Researchers, policymakers, } \\
\text { ministries, WHO, public }\end{array}$ & $\begin{array}{l}\text { Active-presented findings, } \\
\text { led discussions }\end{array}$ & Yes \\
\hline $\begin{array}{l}\text { Mbonye } \\
\text { et al. } 2013 \\
\text { [25] }\end{array}$ & Uganda & Not reported & $\begin{array}{l}\text { Malaria, infectious and } \\
\text { communicable diseases }\end{array}$ & $\begin{array}{l}\text { Researchers, policymakers, } \\
\text { civil society, media }\end{array}$ & $\begin{array}{l}\text { Active-developed and } \\
\text { reviewed policy briefs, } \\
\text { participated in policy } \\
\text { workshops }\end{array}$ & Yes \\
\hline $\begin{array}{l}\text { Mc Sween- } \\
\text { Cadieux } \\
\text { et al. } 2018 \\
\text { [26] }\end{array}$ & Burkina Faso & $\begin{array}{l}\text { Mixed } \\
\text { methods }\end{array}$ & Road traffic injuries & $\begin{array}{l}\text { Researchers, health } \\
\text { professionals, civil society, } \\
\text { police, government }\end{array}$ & $\begin{array}{l}\text { Active-conducted research, } \\
\text { organized policy workshop }\end{array}$ & Yes \\
\hline $\begin{array}{l}\text { Mubyazi } \\
\text { et al. } 2005 \\
{[27]}\end{array}$ & Tanzania & Case study & Antimalarial drug policy & $\begin{array}{l}\text { Researchers, policymakers, } \\
\text { drug manufacturers, } \\
\text { media, practitioners, } \\
\text { public }\end{array}$ & $\begin{array}{l}\text { Active-generated evidence, } \\
\text { disseminated findings, } \\
\text { participated in discussions }\end{array}$ & Yes \\
\hline $\begin{array}{l}\text { Nabyonga- } \\
\text { Orem et al. } \\
2014 \text { [28] }\end{array}$ & Uganda & Case study & $\begin{array}{l}\text { Malaria treatment policy } \\
\text { change }\end{array}$ & $\begin{array}{l}\text { Researchers, policymakers, } \\
\text { MoH, donors, } \\
\text { parliamentarians, civil } \\
\text { society, media, } \\
\text { communities }\end{array}$ & $\begin{array}{l}\text { Active-generated evidence, } \\
\text { participated in policy } \\
\text { development }\end{array}$ & Yes \\
\hline $\begin{array}{l}\text { Nabyonga- } \\
\text { Orem et al. } \\
2016 \text { [29] }\end{array}$ & Liberia & Case study & $\begin{array}{l}\text { Policy dialogue before and } \\
\text { after the Ebola outbreak }\end{array}$ & $\begin{array}{l}\text { Policymakers, donors, } \\
\mathrm{NGO} \text {, policy } \\
\text { implementers, } \mathrm{MoH}\end{array}$ & Not reported & $\begin{array}{l}\text { Not } \\
\text { reported }\end{array}$ \\
\hline $\begin{array}{l}\text { Odoch et al. } \\
2015 \text { [30] }\end{array}$ & Uganda & Desk review & $\begin{array}{l}\text { Male circumcision for HIV } \\
\text { prevention }\end{array}$ & $\begin{array}{l}\text { Researchers, MoH, donors, } \\
\text { media, civil society, public }\end{array}$ & $\begin{array}{l}\text { Active-generated evidence, } \\
\text { participated in policy }\end{array}$ & Yes \\
\hline
\end{tabular}


Table 1 Characteristics of publications on policy dialogue in Africa (Continued)

\begin{tabular}{|c|c|c|c|c|c|c|}
\hline $\begin{array}{l}\text { Author and } \\
\text { date }\end{array}$ & Country & Study type & Public health issue & $\begin{array}{l}\text { Participants in policy } \\
\text { dialogue }\end{array}$ & Role of researchers & $\begin{array}{l}\text { Presence } \\
\text { of local } \\
\text { researchers }\end{array}$ \\
\hline & & & & & $\begin{array}{l}\text { negotiation, formulation, } \\
\text { communication, and } \\
\text { implementation }\end{array}$ & \\
\hline $\begin{array}{l}\text { Ongolo- } \\
\text { Zogo et al. } \\
2014 \text { [31] }\end{array}$ & $\begin{array}{l}\text { Multinational-_ } \\
\text { Cameroon and } \\
\text { Uganda }\end{array}$ & Case study & $\begin{array}{l}\text { "Evidence to policy" around } \\
\text { priority topics }\end{array}$ & $\begin{array}{l}\text { Researchers, policymakers, } \\
\text { international bureaucrats, } \\
\text { knowledge brokers, civil } \\
\text { society, media }\end{array}$ & $\begin{array}{l}\text { Active_-generated evidence, } \\
\text { prepared policy briefs, } \\
\text { organized dialogues }\end{array}$ & Yes \\
\hline $\begin{array}{l}\text { Paul et al. } \\
2020 \text { [32] }\end{array}$ & $\begin{array}{l}\text { Multinational- } \\
\text { Benin and } \\
\text { Senegal }\end{array}$ & Case study & Universal health coverage & $\begin{array}{l}\text { Policymakers, health } \\
\text { professionals, public }\end{array}$ & Not reported & $\begin{array}{l}\text { Not } \\
\text { reported }\end{array}$ \\
\hline $\begin{array}{l}\text { Ridde et al. } \\
2017 \text { [7] }\end{array}$ & $\begin{array}{l}\text { Multinational-_ } \\
\text { Benin, Burkina } \\
\text { Faso, Ivory } \\
\text { Coast, Mali, } \\
\text { Niger, Senegal }\end{array}$ & $\begin{array}{l}\text { Reflective } \\
\text { and cross- } \\
\text { sectional } \\
\text { analysis }\end{array}$ & $\begin{array}{l}\text { New health policies on } \\
\text { health coverage and } \\
\text { employment }\end{array}$ & $\begin{array}{l}\text { High-level decision } \\
\text { makers }\end{array}$ & Not reported & $\begin{array}{l}\text { Not } \\
\text { reported }\end{array}$ \\
\hline $\begin{array}{l}\text { Sabi et al. } \\
2017 \text { [33] }\end{array}$ & South Africa & Case study & $\begin{array}{l}\text { Improvement of HIV/AIDS } \\
\text { health service delivery }\end{array}$ & $\begin{array}{l}\text { Researchers, civil society, } \\
\text { business organizations, } \\
\text { African trade union }\end{array}$ & $\begin{array}{l}\text { Active_developed policy } \\
\text { proposals }\end{array}$ & Yes \\
\hline $\begin{array}{l}\text { Ssengooba } \\
\text { et al. } 2011 \\
\text { [34] }\end{array}$ & Uganda & Case study & $\begin{array}{l}\text { Prevention of mother-to-child } \\
\text { transmission and safe male } \\
\text { circumcision }\end{array}$ & $\begin{array}{l}\text { Researchers, policymakers, } \\
\text { media, donors, public }\end{array}$ & $\begin{array}{l}\text { Active-participated in } \\
\text { policy formulation and } \\
\text { implementation, secured } \\
\text { funding for programs }\end{array}$ & Yes \\
\hline $\begin{array}{l}\text { Uneke et al. } \\
2015 \text { [35] }\end{array}$ & Nigeria & $\begin{array}{l}\text { Cross- } \\
\text { sectional } \\
\text { analysis }\end{array}$ & $\begin{array}{l}\text { Strategies to control } \\
\text { infectious diseases of poverty } \\
\text { (malaria, schistosomiasis, and } \\
\text { lymphatic filariasis) }\end{array}$ & $\begin{array}{l}\text { Researchers, policymakers, } \\
\text { MoH, civil society, health } \\
\text { professionals }\end{array}$ & $\begin{array}{l}\text { Active_-provided support } \\
\text { and mentorship to } \\
\text { policymakers for policy } \\
\text { development, participated in } \\
\text { policy dialogue }\end{array}$ & Yes \\
\hline $\begin{array}{l}\text { Wammanda } \\
\text { et al. } 2020 \\
{[36]}\end{array}$ & Nigeria & Case study & $\begin{array}{l}\text { Serious bacterial infection in } \\
\text { young infants }\end{array}$ & $\begin{array}{l}\text { MoH, WHO, civil society, } \\
\text { policymakers, program } \\
\text { implementers, health } \\
\text { professionals }\end{array}$ & Not reported & $\begin{array}{l}\text { Not } \\
\text { reported }\end{array}$ \\
\hline $\begin{array}{l}\text { Webber } \\
\text { et al. } 2018 \\
\text { [37] }\end{array}$ & Tanzania & $\begin{array}{l}\text { Participatory } \\
\text { action } \\
\text { research }\end{array}$ & Maternal health & $\begin{array}{l}\text { Policymakers, village } \\
\text { leaders, community } \\
\text { members }\end{array}$ & $\begin{array}{l}\text { Passive_organized } \\
\text { participatory action research } \\
\text { and collected data }\end{array}$ & Yes \\
\hline $\begin{array}{l}\text { Woelk et al. } \\
2009 \text { [38] }\end{array}$ & $\begin{array}{l}\text { Multinational- } \\
\text { Mozambique, } \\
\text { South Africa, } \\
\text { Zimbabwe }\end{array}$ & Case study & $\begin{array}{l}\text { Use of magnesium sulphate } \\
\text { in the treatment of eclampsia } \\
\text { in pregnancy; use of } \\
\text { insecticide treated bed nets } \\
\text { and indoor residual } \\
\text { household spraying for } \\
\text { malaria vector control }\end{array}$ & $\begin{array}{l}\text { Researchers, policymakers, } \\
\text { MoH, civil society, } \\
\text { international agencies }\end{array}$ & $\begin{array}{l}\text { Active-generated evidence, } \\
\text { contributed to policy } \\
\text { development and review, } \\
\text { collaborated with health } \\
\text { officials, chaired policy- } \\
\text { making committee }\end{array}$ & Yes \\
\hline $\begin{array}{l}\text { Young et al. } \\
2018 \text { [39] }\end{array}$ & South Africa & Case study & $\begin{array}{l}\text { Use of research evidence in } \\
\text { policy }\end{array}$ & $\begin{array}{l}\text { Policymakers and research } \\
\text { buddies }\end{array}$ & $\begin{array}{l}\text { Active_partnered with } \\
\text { policymakers and provided } \\
\text { scientific support }\end{array}$ & Yes \\
\hline
\end{tabular}

recommendations with other stakeholders [26]. Researchers had an active role in one of the two studies from Tanzania [27], while the other study reported a passive role [37]. Researchers summarized and disseminated evidence, and they developed a research policy brief to highlight antimalarial drug resistance and the need for a policy change; stakeholder workshops were organized by the ministry of health and WHO to discuss evidence and recommendations for policy change [27]. A key facilitator of researchers' involvement in Tanzania included the need for clear communication of research findings. One of the two studies conducted in Ghana reported researchers' involvement in the policy dialogue. Researchers played a central role in trials to generate evidence and develop policy briefs [19]. The other study used WHO technical assistance to appraise evidence and draft policy briefs discussed during policy dialogue with national stakeholders [20]. A key limitation in Ghana was that donors' interests took the priority in the policy agenda. Two of the three studies from Nigeria reported 
researchers' engagement in the policy dialogue process [22, 35]. Uneke and colleagues described a mentorship program that was organized to build capacity of policymakers in developing policy briefs; policymakers drafted policy briefs on the control of infectious diseases of poverty, with technical support and mentorship of researchers [35]. These policy briefs were further evaluated and discussed during a policy dialogue, in which key stakeholders, including researchers, participated [35]. Johnson and colleagues reported on the Nigeria Research Days that were organized to discuss policies on maternal and child health by allowing a dialogue among various stakeholders, including researchers and policymakers [22]. Researchers were engaged in the preliminary phase to prepare for the policy dialogue, presented findings, and participated in discussions during the dialogue [22]. The last study from Nigeria briefly described a policy dialogue organized by the Federal $\mathrm{MoH}$ with the support from WHO to discuss the adoption of the WHO possible serious bacterial infection guideline [36].

Researchers were engaged in the policy dialogue process in Cameroon, Morocco, and Zambia, although there was only one study per country. Morocco, the sole Northern African country included in this review, organized a policy dialogue to discuss health financing [18]. Researchers were involved in synthesizing existing evidence, organizing the policy dialogue, and contributing to the development of national recommendations for a health financing strategy. Facilitators of researchers' engagement included external funding, a preliminary phase to prepare the policy dialogue, and conceptualization of the dialogue to achieve the desired goals (e.g. selection of topics and subject matter experts to facilitate discussions) [18]. In Cameroon, the study described Evidence Informed Policy Network (EVIPNet) and reported researchers' involvement in the development of policy briefs and participation in policy dialogue [31]. Between 2008 and 2012, 12 evidence briefs were produced, and seven policy dialogues were organized; facilitators of successful researchers' involvement reported in this study included the support of external funding and a formal knowledge translation platform, which was comprised of researchers as staff [31]. A multinational study including Zambia reported active participation of researchers throughout the policy-making process [23].

Local researchers were involved in all 18 policy dialogues that reported the participation of researchers. However, studies reviewed did not provide enough information to determine whether local and external researchers had similar or different contributions to policy dialogues.

Studies in multiple Western and Central African countries (Benin, Cabo Verde, Chad, Guinea, Ivory Coast, Liberia, Mali, Niger, and Senegal) did not report researchers' involvement in policy dialogues. In Guinea, researchers did not participate in the policy dialogue, but they evaluated its outcomes [17].

\section{Barriers to researchers' involvement in policy dialogue}

The most common barrier reported was limited funding to support policy dialogue activities $(n=8)$, which include research for evidence generation and stipends or reimbursements for incidental costs to stakeholders attending policy dialogues. Lack of funding influenced the ability to support an appropriate number of participants in the policy dialogue [25] and was reported as an obstacle to sustainability [16]. Reliance on donor funding resulted in donor interests being the priority of the policy agenda [19]. There was also skepticism around research funded by donors because of the possibility of conflict of interest [28]. However, high-level decision makers in the government sometimes expressed doubt about research evidence because of their personal beliefs, cultural values, and concerns regarding the impact of new interventions. For instance, in Uganda, the safe male circumcision policy process was delayed due to opposition from high-level political leaders, who were concerned about feasibility of the intervention and the unintended harmful impact of such a policy on the community as the public might misinterpret the intent of such interventions [34].

Another barrier reported was the absence of knowledge translation platforms $(n=2)$ resulting in decreased communication and dialogue between researchers and policymakers $(n=2)$. Poor collaboration between researchers and stakeholders in health policy (policymakers, civil society, media, industry, and public) hampers learning and translation of research findings, which widens the trust gaps and hinders the development of innovative and effective public health interventions [24].

For researchers, the most reported barrier was lack of relevant data and evidence to inform the policy dialogue $(n=8)$, and few studies reported that research evidence was not relevant to local contexts, highlighting the need for local evidence to support the policy process $(n=4)$. Researchers were more likely to pursue rewarding academic interests that were sometimes disconnected to the needs of the community or policy priorities $(n=2)$. As a result, few studies reported limited availability of researchers in the field of interest $(n=3)$. On the other hand, researchers perceived active involvement in the policy process as time consuming and demanding $(n=$ 3). Instead of being actively engaged in the policy process (dissemination of findings and dialogue with policymakers and other stakeholders), some researchers preferred a "hands off" approach like sharing reports or publications with other stakeholders with no desire for further involvement $(n=2)$. In fact, building trust and 
relationships between policymakers and researchers requires time and commitment from both parties [39].

Among the studies that did not engage researchers in the policy dialogue $(n=8)$ reported barriers included limited funding $(n=3)$, poor methodology and coordination of policy dialogue $(n=2)$, and poor data quality or lack of evidence on the public health issue of interest ( $n$ $=2$ ). Policymakers' limited skills to find and evaluate research evidence led to low uptake of evidence, which created delays in decision-making [6]. A study that evaluated policy dialogues in Benin and Senegal did not acknowledge the participation of researchers as being trivial in policy dialogue processes [32].

Facilitators of researchers' involvement in policy dialogue Out of the 18 studies that reported facilitators of researchers' involvement in policy dialogue, the majority highlighted the need for a knowledge translation platform, a shared platform for exchange and decisionmaking $(n=11)$. This platform may take the form of a research network [38], institutional collaboration [25], regional cooperation [23], forum [29], dissemination workshop [26], or support network like 'research buddies' [39]. Restoration of trust between researchers and policymakers, respect for researchers' objectivity, and careful selection of prominent researchers to facilitate dialogues were reported facilitators of this process $(n=$ $4)$. The demand for scientific evidence $(n=5)$ coupled with simple and clear communication from researchers $(n=2)$ were also major facilitators of researchers' involvement. The availability of funding from donors and their involvement were reported as enabling factors $(n=$ 5). Strong political will $(n=4)$ and preliminary discussions in preparation for the policy dialogue $(n=2)$ were also identified as major facilitators of successful engagement of relevant stakeholders. A preparatory phase helps to better organize the policy dialogue process by identifying the needs of stakeholders before the actual dialogue and meeting their expectations $[18,22]$.

For researchers, incentives for their involvement in policy dialogue included the following: motivation to contribute to public health, leading to advocacy for specific causes $(n=2)$; networking with experts in the field of interest $(n=2)$; and prospects for career development $(n=1)$.

\section{Discussion}

This scoping review aimed to analyse the barriers and facilitators of researchers' involvement in health policy dialogue in Africa. This study found that internal factors (related to researchers) that motivated researchers include advocacy, personal, and professional development. The main factor hampering their involvement in policy dialogue was the absence of a conducive environment, which include financial resources to focus their research on relevant public health issues and to get involved in policy-making activities. External factors (related to the political environment) that enabled researchers' involvement in policy dialogue include the following: an appreciation for researchers' contribution, the presence of a knowledge translation platform, funding, and clear communication between researchers and policymakers. Findings of this scoping review are consistent with other research. Several research studies revealed numerous factors that determine whether and how research evidence is taken into account in decision-making: decision-makers' opinions about research utility, their skill in interpreting and using research evidence, and whether there is a supportive context for its use [2, 40]. Likewise, Moat and colleagues show that decisionmakers are influenced by institutional constraints, interest group pressures, personal convictions and values, external factors such as economic recession or elections, external funding, and research data [12]. It is worth noting that in many African countries, researchers' involvement in health policy dialogue remains sub-optimal. Thirty-three percent of the countries $(n=9)$ represented in this study did not report the participation of researchers in the policy process. In an additional 15\% ( $n$ $=4$ ) of the countries, researchers were involved in only half of the health policy dialogues. Major issues reported in such instances are lack of evidence on public health issues discussed and poor methodology during the policy dialogue. The absence of research evidence during the policy dialogue generally results in the use of anecdotal evidence [20], which hardly yield effective interventions. Participation of researchers in the policy process has also been reported to be beneficial to policymakers because capacity-building activities could be developed to improve their skills regarding evidence-based policymaking processes [16]. This finding highlights the need to develop knowledge translation platforms that encourage the involvement of all key stakeholders in the entire process of health policy-making.

In most African countries, international donors can have an influence on policy processes with a bearing on the proposed solutions [41]. It has been reported that external donors impose their preferences rather than discussing several options for addressing a locally identified problem [42]. However, country ownership and donors' influence has successfully coexisted in several contexts [43]. In this study, local researchers were involved in policy dialogues even when funding originated from international organizations or partnerships. Although the studies reviewed do not provide a distinction between the roles of local and external researchers, the involvement of local researchers was reported where researchers contributed to policy dialogues. Previous 
research has emphasized the importance of engaging local researchers on public health issues relevant to their countries and expertise. Local researchers have pivotal roles to play, first and foremost by assisting the $\mathrm{MoH}$ with key studies and localized and decentralized information. They also have an important advocacy role, i.e. bringing to attention priority health issues and offering options to solve them [9]. In practice, however, stakeholders who provide funding may be perceived as more important than others. A tacit establishment of a certain hierarchy of stakeholders can affect local researchers' abilities to influence health policy dialogues.

In many African countries, the production of research evidence is often very limited [44]. Due to limited funding in the research sector, researchers are highly involved in consultancy tasks. These consultancy contracts require commissioned reports and researchers may not have enough time to increase their ability to apply scientific reflection [45]. Furthermore, evidence shows that researchers' influence on policy is shaped by their reputations as independent researchers that provide credible research and their agility in navigating the local policy landscape and participating in policy debates [45]. Independence is closely linked to financial sustainability. Core funding can help position grantees for policy influence by increasing their independence and credibility, staff reputations, and communication skills. Sustaining this independence over the long-term demands strengthening internal capacities [11].

Engaging policymakers early in the research cycle helps to ensure uptake of evidence. Researchers' ability to influence policies is strongly shaped by external factors, especially political barriers. Their agility in responding to these shifts rests in part on their skills in engaging with stakeholders, so that they are attuned to the environment. Choosing the right points of entry for policy engagement is equally important [46]. WHO stresses the value of closer collaboration between research organizations and the policymakers they seek to influence, so that evidence creation is better aligned with policy priorities [11]. At the same time, researchers need to maintain an ethical and impartial stance, ensuring that multiple perspectives inform their research. Achieving this balance demands considerable skill. Achieving policy influence takes a "whole organization" approach. Strong research institutions alone are insufficient to create a culture of evidence-based policy-making [12]. Citizens must be able to demand accountability and participate in decision-making [47]. It is important that research institutions involve community representatives, the media, and advocates for marginalized groups directly in research, from project proposal to completion stages. This strengthens research design while helping communities understand the value of evidence and their own participation in the policy-making process [10]. Donors can help position researchers for influence through flexible funding arrangements that provide for organizational strengthening, while reinforcing researchers' independence.

To properly evaluate the effectiveness of policy dialogues in Africa, more studies describing policymaking processes around various public health issues need to be published. Out of the 21 countries included in our review, only four countries (15\%) had at least three studies. As more studies per country are being published, a more complete picture of country-level policy landscapes could be presented, and country-specific tailored interventions could be implemented to develop productive and consultative platforms where health policies could be discussed.

\section{Strengths and limitations}

The major strength of this scoping review is the focus on researchers' involvement in health policy dialogues in Africa. Many studies have been published on policy-making processes in various African countries, but there is limited evidence on barriers and facilitators of researchers' involvement in this process. The main limitation of this study is the limited amount of information on the policy-making process available at the country-level as most countries represented in this scoping review had only one publication $(n=11)$ and were sometimes published as part of multinational studies $(n=8)$.

\section{Conclusion}

This review provides an overview of evidence on researchers' involvement in health policy dialogue in Africa and highlights barriers and facilitators of this involvement. The most important factor related to researchers' involvement was the presence of a conducive environment that would support and value research while promoting knowledge translation activities. Such an environment would only be functional with adequate funding, trust and communication between policymakers and researchers, and promising personal and professional development opportunities for researchers. Discrepancies exist across countries and sometimes within a specific country. More than half of the countries represented had partial to no researchers' involvement in policy dialogues. While lowand middle-income countries are still striving to increase the uptake of evidence in health policies, these findings highlight areas for improvement. Further evidence on policy processes within specific settings are needed to better inform interventions or practices. 


\section{Abbreviations}

MoH: Ministry of Health; WHO: World Health Organization

\section{Supplementary Information}

The online version contains supplementary material available at https://doi. org/10.1186/s13643-021-01745-y.

\section{Additional file 1. Study protocol.}

Additional file 2. Description of search strategies in various databases and grey literature. Searches conducted in January 2021.

\section{Acknowledgements}

We thank Dr. Louanne Keenan for reviewing a previous version of this manuscript.

\section{Authors' contributions}

GD conceived the study and developed the protocol with DY, EK-A, and VS SC did the literature searches. DY, GD, EK-A, and VS screened papers for inclusion and extracted data to summarize. DY and GD drafted the manuscript. GD and SY supervised the study. All authors critically reviewed and approved the final manuscript.

\section{Funding}

None.

\section{Availability of data and materials}

No additional data available.

\section{Declarations}

\section{Ethics approval and consent to participate}

Not applicable.

\section{Consent for publication}

Not applicable

\section{Competing interests}

The authors declare that they have no competing interests.

\section{Author details}

${ }^{1}$ University of Maryland Baltimore, Baltimore, USA. ${ }^{2}$ World Health Organization, Geneva, Switzerland. ${ }^{3}$ University of Alberta, Edmonton, Canada. ${ }^{4}$ McMaster University, Hamilton, Canada. ${ }^{5}$ School of International Development and Global Studies, University of Ottawa, 120 University Private, Ottawa, Ontario K1N 6 N5, Canada. ${ }^{6}$ The George Institute for Global Health, Imperial College London, London, UK.

Received: 19 February 2021 Accepted: 14 June 2021

Published online: 27 June 2021

\section{References}

1. Danhoundo G, Wiktorowicz ME, Yaya S. Governance of malaria prevention: how decision-makers' and pregnant women's sensemaking contribute to unintended consequences. Health Care Women Int. 2017;38(3):238-52. https://doi.org/10.1080/07399332.2016.1234483.

2. Tricco AC, Cardoso R, Thomas SM, Motiwala S, Sullivan S, Kealey MR, et al. Barriers and facilitators to uptake of systematic reviews by policy makers and health care managers: a scoping review. Implement Sci. 2016;11:4.

3. Stone DA. Policy paradox: the art of political decision making. 3rd ed. New York: W.W. Norton \& Co; 2012.

4. Nutley SM, Walter I, Davies HT. Using evidence: how research can inform public services. Policy press; 2007. https://doi.org/10.2307/j.ctt9qgwt1.

5. Siron S, Dagenais C, Ridde V. What research tells us about knowledge transfer strategies to improve public health in low-income countries: a scoping review. Int J Public Health. 2015;60(7):849-63. https:/doi.org/10.1007/s00038-015-0716-5.

6. Dovlo D, Nabyonga-Orem J, Estrelli Y, Mwisongo A. Policy dialogues - the "bolts and joints" of policy-making: experiences from Cabo Verde, Chad and Mali. BMC Health Serv Res. 2016;16:327-35.
7. Ridde $\mathrm{V}$, Dagenais $\mathrm{C}$. What we have learnt (so far) about deliberative dialogue for evidence-based policymaking in West Africa. BMJ Glob Health. 2017;2(4):e000432. https://doi.org/10.1136/bmjgh-2017-000432.

8. Mwisongo A, Nabyonga-Orem J, Yao T, Dovlo D. The role of power in health policy dialogues: lessons from African countries. BMC Health Serv Res. 2016;16(Suppl. 4):213. https://doi.org/10.1186/s12913-016-1456-9.

9. Rajan D, Adam T, Husseiny D, Porignon D, Ghaffar A, Schmets G. Policy dialogue: what it is and how it can contribute to evidence-informed decision-making. Briefing Note; 2015.

10. Ellen ME, Leon G, Bouchard G, Ouimet M, Grimshaw JM, Lavis JN. Barriers, facilitators and views about next steps to implementing supports for evidence-informed decision-making in health systems: a qualitative study. Implement Sci. 2014;9(1):179. https://doi.org/10.1186/s13012-014-0179-8.

11. World Health Organization. Investing in knowledge for resilient health systems: strategic plan 2016-2020. 2016.

12. Moat KA, Lavis JN, Abelson J. How contexts and issues influence the use of policy-relevant research syntheses: a critical interpretive synthesis. Milbank Q. 2013;91(3):604-48. https://doi.org/10.1111/1468-0009.12026.

13. Munn Z, Peters MDJ, Stern C, Tufanaru C, MCArthur A, Aromataris E. Systematic review or scoping review? Guidance for authors when choosing between a systematic or scoping review approach. BMC Med Res Methodol. 2018;18(1):143. https://doi.org/10.1186/s12874-018-0611-x.

14. Tricco AC, Lillie E, Zarin W, O'Brien KK, Colquhoun $H$, Levac D, et al, PRISMA Extension for Scoping Reviews (PRISMA-SCR): checklist and explanation. Ann Intern Med. 2018;169(7):467-73. https://doi.org/10.732 6/M18-0850.

15. Peters MDJ, Godfrey C, Mclnerney P, Munn Z, Tricco AC, Khalil H. Chapter 11: Scoping Reviews (2020 version). In: Aromataris E, Munn Z, editors. JBI Manual for Evidence Synthesis. JBl; 2020.

16. Berman J, Mitambo C, Matanje-Mwagomba B, Khan S, Kachimanga C, Wroe E, et al. Building a knowledge translation platform in Malawi to support evidence-informed health policy. Health Res Policy Syst. 2015:13(1):73. https://doi.org/10.1186/s12961-015-0061-4.

17. Ade N, Rene A, Khalifa M, Babila KO, Monono ME, Tarcisse E, et al. Coordination of the health policy dialogue process in Guinea: pre- and post-Ebola. BMC Health Serv Res. 2016;16(Supplement 4):220.

18. Akhnif EH, Hachri H, Belmadani A, Mataria A, Bigdeli M. Policy dialogue and participation: a new way of crafting a national health financing strategy in Morocco. Health Res Policy Syst. 2020;18(1):114-020-00629-2. https://doi. org/10.1186/s12961-020-00629-2.

19. Burris H, Parkhurst J, Adu-Sarkodie Y, Mayaud P. Getting research into policy-Herpes simplex virus type-2 (HSV-2) treatment and HIV infection: international guidelines formulation and the case of Ghana. Health Res Policy Syst. 2011;9(1):S5. https://doi.org/10.1186/1478-4505-9-S1-S5.

20. De Carvalho IA, Byles J, Aquah C, Amofah G, Biritwum R, Panisset U, et al. Informing evidence-based policies for ageing and health in Ghana. Bull World Health Organ. 2015;93(1):47-51.

21. Dossou J, Cresswell JA, Makoutode P, De Brouwere V, Witter S, Filippi V, et al. 'Rowing against the current': the policy process and effects of removing user fees for caesarean sections in Benin. BMJ Glob Health. 2018; 3(1):e000537.

22. Johnson EAK, Sombié I, Uzochukwu BSC, Uneke JC, Amadou M, Abosede A, Adebimpi A, Okolo S. Policy dialogue to support maternal newborn child health evidence use in policymaking: The lessons learnt from the Nigeria research days first edition. Afr J Reprod Health. 2020;24(4):109-21. https:// doi.org/10.29063/ajrh2020/v24i4.12

23. Kinoti SN, Gaffikin L, Benson J. How research can affect policy and programme advocacy: example from a three-country study on abortion complications in sub-Saharan Africa. East Afr Med J. 2004;81(2):63-70.

24. Kirigia JM, Pannenborg CO, Amore LG, Ghannem H, IJsselmuiden C, Nabyonga-Orem J. Global Forum 2015 dialogue on "From evidence to policy - thinking outside the box": perspectives to improve evidence uptake and good practices in the African Region. BMC Health Serv Res. 2016; 16(Supplement 4):215.

25. Mbonye AK, Magnussen P. Translating health research evidence into policy and practice in Uganda. Malar J. 2013;12(1):274. https://doi.org/10.1186/14 75-2875-12-274

26. Mc Sween-Cadieux E, Dagenais C, Ridde V. A deliberative dialogue as a knowledge translation strategy on road traffic injuries in Burkina Faso: a mixed-method evaluation. Health Res Policy Syst. 2018;16(1):113. https://doi. org/10.1186/s12961-018-0388-8. 
27. Mubyazi GM, Gonzalez-Block MA. Research influence on antimalarial drug policy change in Tanzania: case study of replacing chloroquine with sulfadoxine-pyrimethamine as the first-line drug. Malar J. 2005;4(1):51. https://doi.org/10.1186/1475-2875-4-51.

28. Nabyonga-Orem J, Nanyunja M, Marchal B, Criel B, Ssengooba F. The roles and influence of actors in the uptake of evidence: the case of malaria treatment policy change in Uganda. Implement Sci. 2014;9(1):150. https:// doi.org/10.1186/s13012-014-0150-8.

29. Nabyonga-Orem J, Gebrikidane M, Mwisongo A. Assessing policy dialogues and the role of context: Liberian case study before and during the Ebola outbreak. BMC Health Serv Res. 2016;16(Supplement 4):219.

30. Odoch WD, Kabali K, Ankunda R, Zulu JM, Tetui M. Introduction of male circumcision for HIV prevention in Uganda: analysis of the policy process. Health Res Policy Syst. 2015;13(1):31

31. Ongolo-Zogo P, Lavis JN, Tomson G, Sewankambo NK. Initiatives supporting evidence informed health system policymaking in Cameroon and Uganda: a comparative historical case study. BMC Health Serv Res. 2014;14:612.

32. Paul E, Fecher F, Deville C, Ndiaye Y, Sall FL, N'koué Emmanuel Sambiéni, et al. Long way to Universal Health Coverage (UHC): are policy dialogue processes appropriate to negotiate trade-offs in Africa?: The Cases of Benin and Senegal. CIRIEC International, Université de Liège; 2020.

33. Sabi SC, Rieker M. The role of civil society in health policy making in South Africa: a review of the strategies adopted by the Treatment Action Campaign. Afr J AIDS Res. 2017;16(1):57-64.

34. Ssengooba F, Atuyambe L, Kiwanuka SN, Puvanachandra P, Glass N, Hyder AA. Research translation to inform national health policies: learning from multiple perspectives in Uganda. BMC Int Health Hum Rights. 2011;11(1): S13. https://doi.org/10.1186/1472-698X-11-S1-S13.

35. Uneke CJ, Ebeh Ezeoha A, Uro-Chukwu H, Ezeonu CT, Ogbu O, Onwe F, et al. Promoting evidence to policy link on the control of infectious diseases of poverty in Nigeria: outcome of a multi-stakeholders policy dialogue. Health Promot Perspect. 2015;5(2):104-15. https://doi.org/10.15171/hpp.2015.013.

36. Wammanda RD, Adamu SA, Joshua HD, Nisar YB, Qazi SA, Aboubaker S, et al. Implementation of the WHO guideline on treatment of young infants with signs of possible serious bacterial infection when hospital referral is not feasible in rural Zaria, Nigeria: challenges and solutions. PLoS One. 2020; 15(3):e0228718. https://doi.org/10.1371/journal.pone.0228718.

37. Webber G, Chirangi B, Magatti N. Community member and policy maker priorities in improving maternal health in rural Tanzania. Int J Gynaecol Obstet. 2018;141(1):80-4. https://doi.org/10.1002/ijgo.12435.

38. Woelk G, Daniels K, Cliff J, Lewin S, Sevene E, Fernandes B, et al. Translating research into policy: lessons learned from eclampsia treatment and malaria control in three southern African countries. Health Res Policy Syst. 2009;7(1): 31. https://doi.org/10.1186/1478-4505-7-31.

39. Young T, Shearer JC, Naude C, Kredo T, Wiysonge CS, Garner P. Researcher and policymaker dialogue: the Policy BUDDIES Project in Western Cape Province, South Africa. BMJ Glob Health. 2018;3(6):e001130. https://doi.org/1 0.1136/bmjgh-2018-001130.

40. Lysenko LV, Abrami PC, Bernard RM, Dagenais C, Janosz M. Educational Research in Educational Practice: Predictors of Use. CJE/RCE [Internet]. 2014; 37(2):1-26. Available from: https://journals.sfu.ca/cje/index.php/cje-rce/a rticle/view/1477. Accessed 22 June 2021.

41. Ottersen T, Elovainio R, Evans DB, McCoy D, Mcintyre D, Meheus F, et al. Towards a coherent global framework for health financing: recommendations and recent developments. Health Econ Policy Law. 2017; 12(2):285-96. https://doi.org/10.1017/S1744133116000505.

42. Naudet J. Trouver des problèmes aux solutions Vingt ans d'aide au Sahel: Vingt ans d'aide au Sahel: OECD Publishing; 1999. https:/doi.org/10.1787/9789264272903-fr.

43. Gautier L, Ridde V. Health financing policies in Sub-Saharan Africa: government ownership or donors' influence? A scoping review of policymaking processes. Glob Health Res Policy. 2017;2(1):23. https://doi.org/10.1186/s41256-017-0043-x

44. Sombie I, Aidam J, Konate B, Some TD, Kambou SS. The state of the research for health environment in the ministries of health of the Economic Community of the West African States (ECOWAS). Health Res Policy Syst. 2013;11(1):35. https://doi.org/10.1186/1478-4505-11-35.

45. De Sardan JO. Promouvoir la recherche face à la consultance. Autour de l'expérience du lasdel (Niger-Bénin). Cahiers d'études africaines. 2011:51(202203):511-28. https://doi.org/10.4000/etudesafricaines.16759.
46. Robert E, Rajan D, Koch K, Muggleworth Weaver A, Porignon D, Ridde V. Policy dialogue as a collaborative tool for multistakeholder health governance: a scoping study. BMJ Glob Health. 2020;4(Suppl 7). https:/doi.org/10.1136/bmjgh-201 9-002161.

47. Danhoundo G, Nasiri K, Wiktorowicz ME. Improving social accountability processes in the health sector in sub-Saharan Africa: a systematic review. BMC Public Health. 2018;18(1):497. https://doi.org/10.1186/s12889-018-5407-8.

\section{Publisher's Note}

Springer Nature remains neutral with regard to jurisdictional claims in published maps and institutional affiliations.
Ready to submit your research? Choose BMC and benefit from:

- fast, convenient online submission

- thorough peer review by experienced researchers in your field

- rapid publication on acceptance

- support for research data, including large and complex data types

- gold Open Access which fosters wider collaboration and increased citations

- maximum visibility for your research: over $100 \mathrm{M}$ website views per year

At BMC, research is always in progress.

Learn more biomedcentral.com/submissions 